\title{
Seed Germination Enhancement through Breaking Seed Dormancy: A Review in Tropical and Temperate Tree Species
}

\author{
Amanpreet Kaur*, Avtar Singh and Rajesh Monga \\ ${ }^{1}$ Department of Silviculture and Agroforestry, ${ }^{3}$ Department of Tree Improvement and Genetic \\ Resources, Dr. Yaswant Singh Parmar University of Horticulture and Forestry, Solan, \\ Himachal Pardesh 173230, India \\ ${ }^{2}$ Department of Forestry and Natural Resources, Punjab Agriculture University, Ludhiana, \\ Punjab, 141004, India \\ *Corresponding author
}

\section{A B S T R A C T}

\section{Keywords}

Dormancy, Growth regulators, Scarification, Stratification, Irradiation, etc

\section{Article Info}

Accepted: 15 August 2020 Available Online: 10 September 2020
The most important factor for the success of plantation is readily availability of quality seeds. In favorable climatic conditions with optimum moisture and temperature most of the tree species germinate quickly and in unfavorable conditions some degree of seed dormancy occurs. There are various kinds of dormancy occur in trees species such as; exogenous dormancy due to hard seed coat, seed coat impermeable to water, presences of chemical; endogenous dormancy due to immaturity of embryo, oxidation and presence of inhibitors; and double dormancy which include both seed coat and embryo dormancy. In most of tropical tree seeds, physical dormancy occurred because of hard seed coat whereas temperate trees seeds mainly have physiological dormancy. There are various methods to deal with different kinds of dormancy i.e. through Scarification, Stratification, Chemical, Biological, and Irradiation methods.(I) Scarification which is done in hard seed coated species such as Acacia spp., Albizia lebbeck, Cassia spp., Santalum album, Terminalia arjuna etc. Mechanical scarification and concentrated $\mathrm{H}_{2} \mathrm{SO}_{4}$ have been widely used to improve germination of several hard seed species, but the level of seed coat thickness among various species is the reason for different responses to all treatments. (II) Stratification is done to remove physiological and morphological dormancy. Most of the Conifers generally have physiological dormancy, stratification for $0-5^{\circ} \mathrm{C}$ for $60-70$ days is better to overcome this kind of dormancy. (III) Chemical methods include use of growth regulator and chemicals for dormancy breaking. Growth hormones such as gibberellins, IAA and Kinetin etc. are mostly associated with seed germination and seedling physiology. Among all growth regulators $\mathrm{GA}_{3}$ is most commonly used for germination enhancement @ 100-200 ppm for 1-2 h in most of the species. $\mathrm{KNO}_{3}$ is important chemical for germination enhancement in many species such as Acacia nilotica, Melia azedarach etc. (IV) Biological method by passing through digestive tracts of animals like seeds of Acacia senegal and (V) Irradiation method irradiate seeds with like X-rays, light rays, gamma rays etc. So, breaking seed dormancy is necessary for seed germination enhancement in nursery. 


\section{Introduction}

A Seed has been defined as a "mature ovule" or a reproductive unit formed from fertilized ovule consisting of an embryo, reserve food and a protective cover. Based on storage seeds are mainly two kinds viz. Orthodox seed having low moisture content ( $<5$ to $10 \%)$ and successfully stored at low or sub-freezing temperature for long time e.g. Acacia, Prosopsis, Pinus, Eucalyptus, Picea, Betula etc. Recalcitrant seed having high moisture content (20-25\%), which cannot be stored successfully for long period. Seed are sensitive to low temperature, chilling damage and death may occur if stored in low temperature e.g. Azardiracta, Quercus, Willow, and Poplar etc. Other than this there is also an intermediate seed which exhibit the drying tolerance characteristic of orthodox seed but are sensitive to low temperature storage like recalcitrant seed.

Dormancy is an inherent state of growth that is found among all life forms (Footitt et al., 2011; Finch- Savage and Leubner-Metzger, 2006). However, dormancy of seeds in plants elucidated as inborn limitation on germination under circumstances that would otherwise encourage germination in non-dormant seeds. In favorable conditions, dormancy is state which enable seeds to avoid germination. Plants also disperse their progeny across time to avoid risk against uncertain environmental conditions by producing seeds with varying levels of dormancy (Venable, 2007; Poisot et al., 2011). Rather, non-dormant seed germinate as quickly as commendatory conditions occurs and thereby reduce the risk of seed predation and escalate the growing season. Factor affecting seed dormancy are internal chemical inhibitors which may need to degrade or need to leach out, immature embryo needing an after-ripening period for internal chemical changes, oxygen content reaching the embryo, hard impermeable seed coats disallowing water imbibition, light and darkness requirement involving light intensity level or wavelength. Fundamentally, dormant or non-dormant seeds govern the habitat experiences by plants and it is key constituents of plant life histories (Donohue et al., 2005).

Dormancy includes; Exogenous dormancy (Seed coat D) which is further divided into physical, chemical and mechanical dormancy a) Physical dormancy occurs where seed coat is impermeable to water and gaseous due to hardened endocarp. Such seed coats develop during the last stage of seed development e.g. Acacia, Cassia, Prosopsis, Albizia etc., b) Chemical dormancy occurs due to presence of chemical inhibitor in outer covering of many seeds. It may be present in other tissue surrounding the embryo like endosperm e.g. Betula etc. c) Mechanical dormancy due to hard seed coat does not allow embryo to expand during germination e.g. Terminalia spp. Melia spp. etc. Another is Endogenous dormancy which includes physiological and morphological dormancy a) Physiological dormancy in which seed coat resist transfer of oxygen to embryo and presence of inhibitors like phenols which fix oxygen by oxidation and limit the availability of oxygen to embryo and leads to problem in germination which is further of three kinds; shallow, deep and intermediate dormancy. Shallow dormancy is for short term and lasts for 1-6 months. It may be due to inhibitors and control of gas exchange (oxygen). It occurs due to high temperature i.e. Thermo dormancy (Quercus, Pinus, Eucalyptus, Fagus etc.) and due to light i.e. Photo dormancy (Betula, Eucalyptus, Ficus, etc.). Deep dormancy controls by the factors within the embryo itself. It occurs in most temperate trees. It can be controlled by natural stratification or cold Stratification or moist chilling e.g. Apple, Juniper, and Taxus etc. Intermediate dormancy the control mechanism thought to be in seed coats and in 
tissues surrounding embryo. It can be broken down by chilling, stratification and Gibberllic acid. (E.g. Conifers). b) Morphological dormancy in which embryo is not fully developed at the time of ripening. It needs additional period for embryo growth after the seed is separated from the plant. This dormancy is broken by alternate warm and cold temperature, gibberllic acid treatment. E.g. Fraxinus, Gingko etc. ExEndo/combined dormancy is caused by factor related to seed coat as well as embryo. It may be caused either by physiological deficiency in the embryonic axis or due to presence of metabolic blocks within the cotyledons. E.g. Emblica officinalis, Gmelina Arborea etc.

Seed germination enhancement is the application of physical, physiological, biological and chemical agents to the seed in order to enhance the physical, physiological, genetical, biochemical and health qualities of seed. It can be achieved through Physical methods/Scarification, Physiological method/Stratification, Chemical method/ soaking in growth regulator or chemicals, biological method and irradiation method. Moreover, there is also germination augmenting treatments like Seed fortification, Seed Priming Hardening, Bio fertilizer treatment etc.,

Seed coating treatments like Seed pelleting, Coloring etc., Protective seed treatments like Insecticide, Fungicide etc., but here we focused on dormancy part only. Dormancy breaking treatments, literature findings, and discussion are described in this review paper as in following sub-headings:

Scarification/ Physical Method

Stratification / Physiological Method

Chemical Method

Biological method

Irradiation method

\section{Scarification/ physical method}

It is a method of disrupting an impermeable seed coat of seeds. This method includes followings types mention in Table 1.

Kullar (1991) reported that seeds of many leguminous families having impermeable seed coat such as species of Cassia, Acacia, and Albizia etc. In majority of the forestry species seed coat dormancy occurs which is due to structure surrounding the embryo. Gehlot and Sen (1998) studied that embryo endure dormant stage while covered in the seed coat but germinate if seed coat is punctured or isolated and cultured on the appropriate medium. Study was conducted on Acacia mangnium due to rapid growth and liberality to very acid and infertile soil and is most suitable species for commercialization, reforestation and environment protection. Experiment was performed with different scarification treatment of conc. $\mathrm{H}_{2} \mathrm{SO}_{4}$ for $(0.5,1,2,3,5,10,15$ minutes) and control. Results were observed after 10 days of treatment. They found that maximum germination percent $90.67 \%$ was obtained in 10 minutes scarification followed by 5 minutes $(89.33 \%)$ and 3 minutes $(82.67 \%)$. But in control (without scarified seed) minimum germination percent $(6.67 \%)$ was obtained.

Azad et al (2010) conducted study in five different treatments i.e. control, cold water $\left(4^{\circ} \mathrm{C}\right)$ immersion in for $12 \mathrm{~h}$, hot water $\left(80^{\circ} \mathrm{C}\right)$ immersion in for $10 \mathrm{~min}$, scarification of seeds with sand paper, concentrated $\mathrm{H}_{2} \mathrm{SO}_{4}$ $(80 \%)$ immersion in for $20 \mathrm{~min}$, to determine methods that maximized germination percentages. Poly-bags media taken was in the ratio of 3:4:1:1 (contains topsoil, coconut husk compost, coarse sand and fine sand). Germination percentage observed in scarification (80\%), concentrated $\mathrm{H}_{2} \mathrm{SO}_{4} 80 \%$ immersion for $20 \mathrm{~min}$ (74\%), hot water 
treatment $(69 \%)$, it shows no significant difference with each other rather all the treatments differed significantly with control i.e. $48 \%$. In $\mathrm{H}_{2} \mathrm{SO}_{4}$ treatment, germination started first (on $8^{\text {th }}$ day), in hot water (on $9^{\text {th }}$ day), in control and sand paper scarification (on $10^{\text {th }}$ day) and, in cold water treatment $\left(11^{\text {th }}\right.$ day). Similar germination pattern is due to thinned outer coat of the seeds.

Best pre sowing seed treatment for Acacia catechu seeds and Elaeocarpus floribundus seeds studied by Das N (2014). It is based on six pre sowing treatments at the nursery stage that includes: (i) control, (ii) immersion of seeds in hot water for $10 \mathrm{~min}$ in $80^{\circ} \mathrm{C}$, after that dipping in cold water $24 \mathrm{hrs}$. (iii) Immersion of seeds in cold water $4^{\circ} \mathrm{C}$ for 24 hrs.(iv) Immersion of in hot water $100^{\circ} \mathrm{C}$ for $12 \mathrm{~min}$ after that dipping in cold water for 24 hrs. (v) Immersion of seeds for $20 \mathrm{~min}$ in concentrated $\mathrm{H}_{2} \mathrm{SO}_{4}(80 \%)$ (vi) Scarification of seeds with sand paper. Highest germination percentage $(91.26 \%)$ in Acacia catechu was observed in hot water immersion $\left(80^{\circ} \mathrm{C}\right) 10$ min after that dipping in cold water for $24 \mathrm{hrs}$. which was only (69\% in control).

It might be due to it require hot water firstly to break dormancy and after that dipping in cold water for $24 \mathrm{hrs}$. after hot water treatment makes softer seed coat. Whereas, in case of Elaeocarpus floribundus highest germination $89.8 \%$ with $\mathrm{H}_{2} \mathrm{SO}_{4}(80 \%) 20$ min and $86.35 \%$ with immersion of seeds in hot water $100^{\circ} \mathrm{C}$ for $12 \mathrm{~min}$, after that dipping in cold water for $24 \mathrm{hrs}$.

Effect of pre-sowing treatment varies from species to species. Levels of thickness in seed coat among various species are the reason of different degree of response to different pre sowing treatment.

Lots of work has been done by many different scientist for breaking the hard seed coat of different forest species and they found that in Albizia labbeck, Cassia fistula, and Pinus roxburghii etc. the main reason for the increase in imbibition and germination is seed coat and microphyler plug disintegration. In leguminous tree species, acid treatment shows maximum germination percentage, quick and early emergence of seeds which results from the seed coat softening that allows movement water into the seed and enlargement of the embryo that is induced water absorption and gaseous exchange.

\section{Stratification/physiological method}

Physiological dormancy occurs mostly in conifer seed. So, in coniferous species stratification/physiological method is one of the widely used methods to enhance germination percentage by breaking seed dormancy. It can be done with various temperatures and in humid and dry conditions that last for few weeks and months. It is done by two methods i.e. cold stratification and warm stratification.

\section{Cold stratification}

In this method, Seeds are imbibed at low temp $\left(3-5^{\circ} \mathrm{C}\right)$ for a period of time $(48 \mathrm{~h})$ and then draining of water and seeds are mixed with moist (sand, sand peat mixture etc.) 2-4 times of their volume and stored at cold temperature $3-5^{\circ} \mathrm{C}$.

Biochemical activity due to high moisture and low temp, transforms complicated food material to simple forms that is taken by embryo, and micro-organisms activity is also reduced. It is done to break physiological and morphological Dormancy. Study shows that cold ST induces a response to gibberellic acid and initiated cell division resulting in release of physiological dormancy and subsequent germination in Taxus chinensis seeds Zhang et al (2013). 


\section{Warm stratification}

In this method, Seeds are imbibed in cold water at $3-5^{\circ} \mathrm{C}$ for a period of time $(48 \mathrm{~h})$ and then draining of water and seeds are mixed with moist or water retained medium (sand, sand peat mixture etc.) 2-4 times of their volume and stored at warm temperature 20$25^{\circ} \mathrm{C}$. Partial digestion of the outer layer and final weakening of inner layer results in increased oxygen uptake and energy to embryonic growth, cell expansion, increase $\mathrm{GA}_{3}$ and deceased ABA level. It is done to break physical, mechanical and morphological Dormancy. Studies shows that warm ST increased the growth of embryo by cell expansion and enlargement in Taxus chinensis seeds (Zhang et al., 2013).

Conifers seed in generally has extreme dormancy even in the favorable environment conditions for its germination as studied by Jull and Blaich (2000). Dormancy in seeds is due to internal and external factors. For seed germination improvement cold stratification before sowing has been widely used for disrupting dormancy (Baskin and Baskin, 2004). Muglo (2013) conducted study with different stratification temperature and period to observe germination percentage. Different treatments take were Stratification period i.e. 15, 30, 45, 60, 75, 90, 105, 120 days and Stratification temperature $0 \pm 1{ }^{\circ} \mathrm{C}, \quad 4 \pm 1{ }^{\circ} \mathrm{C}$, control. Highest germination percentage $(62 \%)$ was observed in $0 \pm 1^{\circ} \mathrm{C}$ temperature between 60 to 90 days, thereafter germination period decrease with increase in stratification period.

Gosling (2015) conducted study on Betula utilis (Himalayan birch) seeds having intermediate dormancy. Mir et al (2018) studies on germination ability and performance of Betula utilis under field. Stratification and $\mathrm{GA}_{3}$ treatment is method to overcome embryo dormancy. Stratification of seeds at $4 \pm 1{ }^{\circ} \mathrm{C}$ for different time period i.e. 0, 30, 60, 90 days and then these seeds were treated with $\mathrm{GA}_{3}$ i.e. $0 \mathrm{ppm}, 50 \mathrm{ppm}$ and 100 ppm for $2 \mathrm{~h}$. Results show that with increasing stratification duration and $\mathrm{GA}_{3}$ concentration, there is significant increase in germination percentage and energy. The maximum and minimum germination $(89.11 \%, 53.33 \%)$ and germination energy (38.22, 28.22) were recorded in stratified seeds for (90 days and with100 ppm $\mathrm{GA}_{3}$ ) and control.

Gosling, 2015 suggests different species requires different stratification period as shown in figure 1: Abies alba, A. balsamea, A. concolor, A. fraseri, A. grandis, A. procera require 8 weeks of stratification. Cedrus atlantica, Cedrus deodara also requires 8 weeks stratification. Juniperus communis needs 24 weeks of stratification. Picea abies, $P$. omorika, $P$. pungens, $P$. sitchensis requires 6 weeks of stratification, Pinus contorta, Pinus muricata, Pinus nigra, Pinus pinaster, Pinus radiate, Pinus sylvestris also requires 6 weeks of stratification whereas, Taxus baccata needs 40 weeks of stratification.

Various physiological changes total sugars and starch content occur in seeds during stratification method. Stratification activating enzymes such as amylase, protease and lipase which is liable for solubilizing spare food material in the form of starch, protein in seed and deliver energy and other food material to germinating embryo thus allowing dormancy release. Higher germination as compared to control i.e. without stratification might be due to conversion of starch (used for embryo growth and development). Growth promoting substances such as increase in GA or cytokines level inhibit the effect of retardants like ABA (Paul et al., 1973). Low temperature and stratification period results in biochemical changes in seeds that is useful during germination by transforming 
complicate food material into simpler forms (Malik et al., 2008). Tanaka et al (1991) also reported that during stratification lower temperature enhance germination ability in conifers. Physiological method reduces the rate of enzymatic reactions in the seed and cause distinctive changes i.e. in enzyme concentrations or production and phase changes i.e. in membrane fluidity. It also triggers enzymes and hormones production thereby release dormancy reported by Bewley and Black (1994). Increase in seed germination may be due to increase in soluble protein and sugar with increase in stratification duration. This biochemical changes may be responsible for high germination parameter of seed or it is due to increase in GA level in the seed which result in hydrolase synthesis in the seed which causes breakdown of starch into sugar. Allen (1962) reported that in coniferous seed longer $\mathrm{ST}$ period is better.

\section{Chemical Method}

This method is also widely used in different species it consists of soaking of seeds in growth regulator, chemicals, new generation plant growth regulators which are represented in table 3,4 , and 5 .

Azad et al., (2010) conducted study on Melia azedarach a highly valuable multipurpose tree species, so for quality planting stock their vigor's seed with uniform germination is necessary but, main difficulty in this species is its poor seed germination. So, this study was conducted to obtain highest germination percentage with different treatments Viz., Cold water (24hrs), Hot water (10 $\mathrm{min})$, Concentrated $\mathrm{H}_{2} \mathrm{SO}_{4}$ (10 min dipping), $\mathrm{KNO}_{3}$ (200 M for $24 \mathrm{~h}$ ), Gibberllic acid (100 ppm for $8 \mathrm{~h}$ ), Cow dung slurry (1:4 for 6 days), Biogas slurry (6 days), Mini-sachet method (5 days) and Control. After 60 day of sowing, among the all treatments, highest germination percentage was observed from $84 \%$ in $\mathrm{KNO}_{3}$ followed by $70.7 \%$ in biogas slurry and $70 \%$ in cow dung slurry these were significantly better than other treatments and at par with each other. Ali et al (2010) reported that increased germination with $\mathrm{KNO}_{3}$ solution may be due to; reducing the growth retardant (ABA) and enhanced imbibition of water into cotyledons that create hormonal balance in the seed. Whereas, in case of biogas slurry and cow dung slurry, germination percentage increase is due to increase in microbial population, due to anaerobic condition and moderate temperature seed germination is triggered (Sujatha et al., 2007).

Mugloo J A (2013) reported the effects of various treatment on germination of spruce using different treatments viz., control, cold water for 24 and $48 \mathrm{hr}, \mathrm{GA}_{3}$ (50ppm, 100ppm, 150ppm, 200ppm, $250 \mathrm{ppm}$ ) for 24 and 48 hour. Significantly highest germination percent was obtained from $\mathrm{GA}_{3} 200$ ppm for $48 \mathrm{~h}$ treatment which was $30 \%$ in case of control and $35 \%$ in cold water treatment, these both shows lesser percentage compared to other treatments. Increase in germination percentage in $\mathrm{GA}_{3}$ is might be due to increase the growth potential of embryo and by weakening of layers surrounding the seed that weaken the tissue around the radicle which results in improved growth.

Study was conducted by Rawat et al (2006) at three districts viz., Pauri, Tehri and Chamoli of Garhwal Himalaya. Aim is to understand the role of $\mathrm{GA}_{3}$ treatment for seed germination in different provenances of Abies pindrow, Cupressus torulosa and Picea smithiana. Five provenances each of three important coniferous species (15 provenances) were taken. They were subjected to different treatments i.e. soaking of seeds in distilled water at $25{ }^{\circ} \mathrm{C}$ for $24 \mathrm{hr}$, soaking of seed in $\mathrm{GA}_{3} 100 \mathrm{ppm}$ for $24 \mathrm{hr}$. In Abies pindrow $45 \%$ germination percentage 
was achieved with $\mathrm{GA}_{3}$ which was only $26 \%$ in control. In Cupressus torulosa $57 \%$ germination percentage was gained after treatment with $\mathrm{GA}_{3}$ which was $25 \%$ in control. Whereas, in case of Picea smithiana $56 \%$ germination was obtained with $\mathrm{GA}_{3}$ and $27 \%$ in control. Seed germination improvement with gibberllic acid might be due to hydrolase synthesis (especially amylase synthesis) which solubilize spare food material in seed in the form of starch or protein and deliver energy and food material to germinating embryo. Growth of embryo further results in more gibberllic acid synthesis, which induced hydrolase synthesis.

Many plant regulators are linked with seed germination enhancement and seedling growth in favorable conditions, but the key hormones are gibberellic acid, Indole-3Acetic-Acid and Kinetin etc. (Faridi et al., 2000). Growth hormones increase in growth potential of embryo, weaken the structure covering the embryo through cell wall hydrolases, counteracts the effect of ABA, reduces photo-D, promotes germination in thermo-D through ABA metabolism, initiation of enzymes, mobilize food substances which leads to cell division, promotes germination in viable seeds through cell division, cell elongation and embryo growth (Pandiya, 1989).

In the course of germination and growth, the total carbohydrates are employed to encounter the pre-condition of respiration, protoplasm material and synthesis of cell wall for dividing cells (Black, 1992). Cytokinins promote germination through ethylene biosynthesis (Matilla, 2000). Ethephon (ethylene releasing compound) take part in radicle cell expansion, Increase seed respiration and water potential, decreasing the sensitivity of ABA etc.

\section{Biological methods}

It involves animals, insects, and microorganism. Pods are fed to sheep or goats. Hard seed coat is softening by the combination of moisture, warmth and chemical action of the digestive juices. It is hard to utilize these agents as a controlled pretreatment of seed, but in some cases positive results were also reported.

Goor and Barney (1976) found that pretreatment of seeds of Acacia Senegal and Ceratonia siliqua collected form droppings of penned goat, overcame seed dormancy and seed germinate quickly when placed in favorable environment condition, which is due to the action of the strong digestive chemicals in digestive tracts of goats. Troup (1921) reported improved germination due to digestive actions of sheep and goat in Acacia nilotica seeds that were discharged after rumination.

In many part of the tropics termites are also a key component for cracking the seed dormancy. In Thailand, after teak fruits collection it is spread in ground in a $5 \mathrm{~cm}$ thick layer and then covered it with cardboard and after about 5 weeks the termites had removed the exocarps. Germination of removed exocarp seed is significantly improved as compared to with intact exocarps [Bryndum (1966), Sompherm (1975)]. Groome et al., (1957) reported that termites also used the same way to shatter sturdy winged and stubble fruits of Pterocarpus angolensis.

Partial fermentation is also beneficial in some species by overcoming seed coat dormancy. Wunder (1966), studied on Tectona grandis fruits that improved germination is obtained through laying the fruits of Tectona on the floor throughout the monsoon season which results in mild fermentation. Then gathered these seeds and stratified in ditch with 
different layers of seed, organic matter and soil and waters it for 10 days. Ahmed, 1986 also found that seeds of Acacia species obtained from goat dropping are non- dormant than seeds which were not feed to goat. It is useful in Acacia senegal, Acacia nilotica, Gmelina arborea, Tectona grandis etc.

Table.1 Different kinds of scarification and research findings

\begin{tabular}{|c|c|c|}
\hline Scarification & Description & Research findings \\
\hline Physical/ Manual & $\begin{array}{l}\text { Clipping with knife, } \\
\text { piercing with needle, } \\
\text { rubbing against rough } \\
\text { surface, cracking } \\
\text { with hammer etc. }\end{array}$ & $\begin{array}{l}\text { Nicking using secateurs gave maximum germination in } \\
\text { Acacia polyacantha reported by Edward M (2014). In } \\
\text { India this method is used to overcome seed coat } \\
\text { dormancy in Albizzia falcataria, A. lebbek, Acacia } \\
\text { catechu, A. nilotica subsp. indica, Cassia fistula, C. } \\
\text { javanica, C. nodosa, Delonix regia, Santalum album, } \\
\text { Terminalia arjuna, T. tomentosa etc. }\end{array}$ \\
\hline Water soaking & $\begin{array}{l}\text { Soaking of seed in } \\
\text { cold and hot water for } \\
\text { few hours to several } \\
\text { days }\end{array}$ & $\begin{array}{l}\text { Schmidt L (2000) reported that } 82-89 \% \text { germination } \\
\text { percentage in Cassia siamea is obtained by soaking } \\
\text { seeds for } 1-2 \text { min in warm water }\left(85^{\circ} \mathrm{C}\right) \text { with subsequent } \\
\text { cooling in the water for } 12-36 \mathrm{hrs} \text {. Soaking of seeds in } \\
\text { water for } 2-48 \text { hrs based on species accelerates } \\
\text { germination in many species such as A. amara, A. } \\
\text { procera, G. robusta T. nudiflora, Acacia mearnsii, A. } \\
\text { melanoxylon, A. nilotica subsp. kraussiana etc. }\end{array}$ \\
\hline Fire & $\begin{array}{l}\text { Light inflammable } \\
\text { litter are spread over } \\
\text { the fruit and then } \\
\text { ignite, done to } \\
\text { partially damage seed } \\
\text { coat }\end{array}$ & $\begin{array}{l}\text { Dry heat ineffective in increasing germination, whereas } \\
\text { moist heat greatly increased both germination rate and } \\
\text { total germination of Lespedeza species of seed found by } \\
\text { Charles et al (1967). }\end{array}$ \\
\hline Acid & $\begin{array}{l}\text { Pouring undiluted } \\
\text { acid until all seeds } \\
\text { are wetted, stirring, } \\
\text { immediately washing } \\
\text { then cooling }\end{array}$ & $\begin{array}{l}\text { Duguma et al (1988) reported } 30 \text { min treatment with } \\
\mathrm{H}_{2} \mathrm{SO}_{4} \text { in Leucaena leucocephala gives } 95 \% \\
\text { germination. Some examples like soaking of Intsia } \\
\text { palembanica for } 60 \mathrm{~min} \text {, Parkia javanica for } 15 \mathrm{~min} \text {, } \\
\text { Dialium maingayi for } 5 \mathrm{~min} \text {, Acacia albida for } 20 \mathrm{~min} \text {, } \\
\text { Acacia nilotica for } 60-80 \mathrm{~min} \text {, Acacia senegal for } 40 \\
\text { min, Acacia planifrons for } 2 \text { hours and Prosopis } \\
\text { tamarugo for } 7 \text { min of tropical species which respond } \\
\text { well to Sulfuric acid treatment. Pterocarpus angolensis } \\
\text { hulled seeds when treated with acid it gave } 60 \% \\
\text { germination between } 4-19 \text { days, in comparison to } \\
\text { control it was } 16 \% \text { between } 11-37 \text { days. }\end{array}$ \\
\hline
\end{tabular}


Table.2 Stratification effect on some important conifers

\begin{tabular}{|l|l|l|l|l|}
\hline Species & Temperature $^{\circ}$ C & PT days & Germination \% & Reporting \\
\hline Cedurs deodara & 5 & 75 & 82.10 & Sofi and Bhardwaj (2008) \\
\hline Abies spectabilis & $1-5$ & $30-120$ & 70 & SFRI information bulletin (1999) \\
\hline Juniperous recurva & $1-5$ & $30-120$ & 50 & Mir et al (2014) \\
\hline Pinus geradiana & $4 \pm 1$ & 60 & 83 & Malik and Shamet (2009) \\
\hline Pinus wallichiana & $1-5$ & $30-120$ & 82 & Mir et al (2014) \\
\hline
\end{tabular}

Table.3 Different kind of growth regulators taking part in dormancy breaking, their functions and research findings

\begin{tabular}{|c|c|c|}
\hline Growth regulator & Functions & Research findings \\
\hline $\begin{array}{l}\text { Gibberellic acid } \\
\text { (found in mersitem of } \\
\text { apical bud and root, } \\
\text { embryo) }\end{array}$ & $\begin{array}{l}\text { Promote seed and bud } \\
\text { germination, take part in Stem } \\
\text { elongation and leaf growth, } \\
\text { Stimulate flowering an } \\
\text { development of fruits, Affect } \\
\text { root growth and differentiation } \\
\text { etc. }\end{array}$ & $\begin{array}{l}\text { Mirzavandiani (2016) reported } 92 \% \\
\text { germination in Pinus radiata with } \mathrm{GA}_{3} \\
300 \mathrm{ppm}+\mathrm{KNO}_{3}(.3) \text { for } 48 \mathrm{~h} \text { whereas } \\
\text { Rawat (2006) studied } 57 \% \text { germination } \\
\text { in Cupressus torulosa with } \mathrm{GA}_{3} \\
\text { 100ppm@ for 24hrs. }\end{array}$ \\
\hline $\begin{array}{l}\text { Kinetin (it is present in } \\
\text { developing seeds) }\end{array}$ & $\begin{array}{l}\text { Take part in Promotion of cell } \\
\text { division in embryo, Release } \\
\text { dormancy, Effect root growth } \\
\text { and differentiation }\end{array}$ & $\begin{array}{l}\text { In Ziziphus mauritiana BA (100ppm) } \\
\text { stimulated both total germination and } \\
\text { vigor of seeds reported by Murthy and } \\
\text { Reddy (1989). }\end{array}$ \\
\hline $\begin{array}{l}\text { Auxins } \\
\text { (found in embryo of } \\
\text { seed, meristem of } \\
\text { apical buds) }\end{array}$ & $\begin{array}{l}\text { Stimulate stem elongation, take } \\
\text { part in Root growth, Enhance } \\
\text { apical dominance etc. }\end{array}$ & $\begin{array}{l}\text { Highest seed germination (91\%) } \\
\text { observed in Pinus massoniana with the } \\
\text { application of IAA 100ppm and GA3 } \\
\text { 50ppm reported by Zhao Guangwu, } \\
\text { (2014). }\end{array}$ \\
\hline $\begin{array}{l}\text { Ethylene } \\
\text { (found in ripening } \\
\text { fruit, nodes of stem) }\end{array}$ & $\begin{array}{l}\text { Stimulate germination, } \\
\text { Alleviates primary and light } \\
\text { induced dormancy etc. }\end{array}$ & $\begin{array}{l}\text { Ethylene plays a key role in dormancy } \\
\text { release in numerous species, the } \\
\text { effective concentrations allowing the } \\
\text { germination of dormant seeds ranging } \\
\text { between } 0.1 \text { to } 200 \mu \mathrm{L} \text { L(-1) reported } \\
\text { by Francoise } \mathrm{C}(2014) \text {. }\end{array}$ \\
\hline $\begin{array}{l}\text { Fusicoccin (Fusicoccin } \\
\text { amygdali) it is a toxin } \\
\text { produced by fungus }\end{array}$ & $\begin{array}{l}\text { Breaking seed dormancy, } \\
\text { Stimulate germination, Eliminate } \\
\text { primary Dormancy }\end{array}$ & $\begin{array}{l}\text { The application of germination } \\
\text { regulating chemicals like fusicoccin, } \\
\text { proline and nitrate almost completely } \\
\text { alleviated the salinity effect on seed } \\
\text { germination studied by Ajmal K } \\
\text { (2009) }\end{array}$ \\
\hline
\end{tabular}


Table.4 Different chemical used in dormancy breaking and research findings

\begin{tabular}{|c|c|}
\hline Chemicals & Scientific findings \\
\hline $\begin{array}{l}\text { Potassium nitrate } \\
\text { (It break dormancy, faster } \\
\text { seed germination and vigour) }\end{array}$ & $\begin{array}{l}\mathrm{KNO}_{3} \text { had a strong effect on germination percentage and vigour of } \\
\text { Acacia nilotica seeds. At 1\% con-centration, germination increased } \\
79 \% \text {, and at } 2 \% \text { conc. It increased to } 85 \% \text { and in control it was } 37 \% \\
\text { reported by Palani et al (1995). }\end{array}$ \\
\hline $\begin{array}{l}\text { Thiourea } \\
\text { (it also take part in Breaking } \\
\text { dormancy, regulator of seed } \\
\text { germination in soil) }\end{array}$ & $\begin{array}{l}\text { In Ziziphus mauritiana, thiourea is proved the most effective } \\
\text { germination stimulant, soaking of seed in } 1 \% \text { solution for } 1 \text { day } \\
\text { increase total germination percentage } 78 \% \text { at } 30^{\circ} \mathrm{C}, 41 \% \text { in control } \\
\text { was found by Lars Schmidt }(2000) \text {. }\end{array}$ \\
\hline $\begin{array}{l}\text { Hydrogen peroxide it is an } \\
\text { active oxygen source, } \\
\text { oxygen can accelerate ABA } \\
\text { degradation, enhancing } \\
\text { oxygen production thereby } \\
\text { promote germination by } \\
\text { breaking Dormancy) }\end{array}$ & $\begin{array}{l}\text { Chien and Tsan (1994) found that in Cinnamomum camphorum } \\
\text { germination is improved with } 15 \% \mathrm{H}_{2} \mathrm{O}_{2} \text { treatment from } 0-11 \% \text { to } \\
51-58 \% \text {. }\end{array}$ \\
\hline $\begin{array}{l}\text { Alcohol } \\
\text { It also Dormancy breaking, } \\
\text { like in the form of ethyl } \\
\text { alcohol and ether }\end{array}$ & $\begin{array}{l}\text { Ethanol treatments (3\%) enhanced the germination of rice to } 100 \% \text {, } \\
\text { which otherwise germinated poorly (30\%) after dehusking studied } \\
\text { by Miyoshi and Sato (1997). }\end{array}$ \\
\hline
\end{tabular}

Table.5 Different kinds of new generation plant growth regulators used in dormancy breaking and research findings

\begin{tabular}{|l|l|l|}
\hline PGR & Role & Research findings \\
\hline $\begin{array}{l}\text { Brassinosteriods } \\
\text { (occurs in every } \\
\text { part of plant) }\end{array}$ & $\begin{array}{l}\text { Take part in breaking Seed } \\
\text { dormancy, Cell elongation and } \\
\text { division, Root and shoot } \\
\text { development, Response to stress } \\
\text { etc. }\end{array}$ & $\begin{array}{l}\text { BR increase the ability of embryo to grow } \\
\text { endosperm reported by Leubner-Metzger } \\
\text { (2001). Highest 49.6\% germinationby BR } \\
\text { observed in Fraxinus as compared to control } \\
20 \% \text { found by Prochazka (2015). }\end{array}$ \\
\hline Jasmonic acid & $\begin{array}{l}\text { Regulate Photosynthesis, take part } \\
\text { in root and shoot growth, Seed } \\
\text { germination, Flowering etc. }\end{array}$ & $\begin{array}{l}\text { Jasmonic acid increased the germination and } \\
\text { rate of germination by 5-10 days in apple } \\
\text { seed as compared to control studied by Yildiz } \\
\text { et al., (2007). }\end{array}$ \\
\hline Salicylic acid & $\begin{array}{l}\text { Promote germination under high } \\
\text { salinity, Influences on increased germination of wheat by 67\% } \\
\text { photosynthesis, enzyme activities, } \\
\text { flowering etc. }\end{array}$ & $\begin{array}{l}\text { under salt stress as compared to control } \\
\text { reported by Bahrani and Pourreza (2012). }\end{array}$ \\
\hline Nitric oxide & $\begin{array}{l}\text { Induces seed germination in the } \\
\text { absence of red light, breaks seed } \\
\text { dormancy, and affects growth etc. }\end{array}$ & $\begin{array}{l}82 \% \text { germination in Empress Trees with NO } \\
10 \text { M and cold stratification reported by Jia } \\
\text { Liu et al (2019). }\end{array}$ \\
\hline
\end{tabular}


Fig.1 Pre-treatment week's requirements for different conifers

Pre-treatment weeks $\left(4^{\circ} \mathrm{C}\right)$

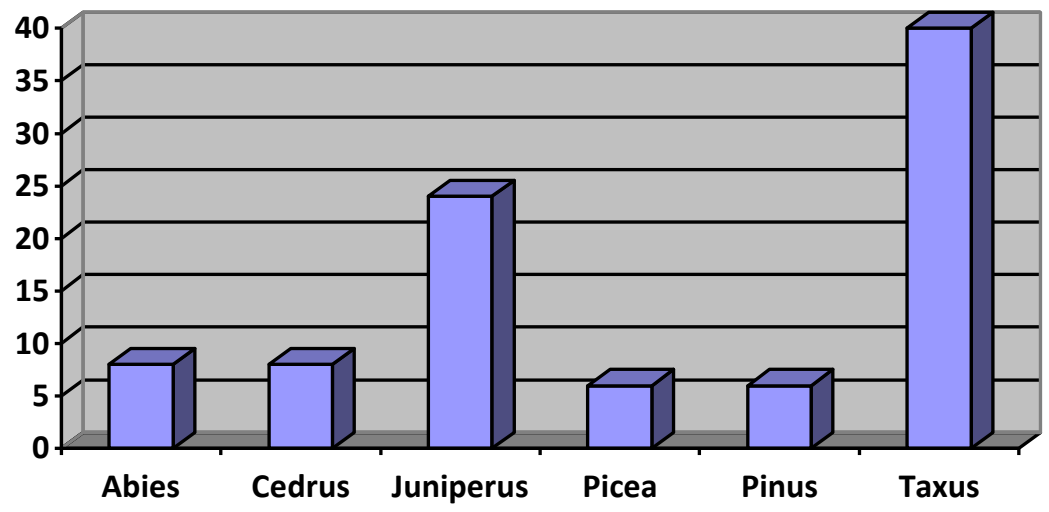

\section{Irradiation method}

Seed is packed with the material and energy necessary for inceptive growth, but some external factors are also required to activate that material that is already present in cotyledons. The red region of the spectrum Xrays, gamma rays, light rays and sound waves have been experimented to stimulate germination and to break dormancy.

There have been reports of improvement in some species including Tectona Bhumibhamon (1973), but most of the studies showed hard to obtain reliable outcome and chromosome damage and other malformations may also cause by the treatments (Kemp, 1975). There were reports of many adverse effects from irradiation than favorable effects. None of this procedure is acceptable for actual application at the present time (Lynn, 1967).

Confiding on the levels of irradiation $\gamma$ irradiation has intense impact on growth by prompting genetically, biochemical, morphogenetic, physiological and cytological changes in tissues and cells. Small doses of irradiation may elevate the enzymatic activation and invigorating of the young embryo, by elevating cell division rate and also influences the vegetative growth but it is also a key for the activation of various biochemical, physiological activities.. It can be useful for altering the physiological characters and improving germination and seedling growth. Cobalt-60 was used to irradiate the seeds of Magnolia champaca with $(0,5,10$, 15, 20, 40, 60, 80, 100 Gy) does. Three lots, namely germination test, storage test and seedling growth characteristics, were made from treated seeds. LD50 for irradiation was near 30 Gy does and at 80 Gy and higher doses irradiation caused lethal effect to the treatments. At $10 \mathrm{~Gy}$ enhancement in all germination parameters were recorded in irradiated seed, and then it was reduced. Up to 80 Gy irradiation dose there is increased in all seedling parameters such as collar diameter, number of leaves, seedling height and dry weight, but the $10 \mathrm{~Gy}$ results in more significant and achieve maximum value for all growth parameters studied by (Chandrasekhar et al., (2013).

Akshatha et al., (2013) studied the impact of gamma irradiation on Terminalia arjuna. Different doses ranging from 0 to $200 \mathrm{~Gy}$ 
using the ${ }^{60} \mathrm{Co}$ source were used and the results were compared with the control plants. In comparison to un-irradiated seeds (control) germination speed at 25 Gy was (0.65) which was double. All the parameters like germination percentage, vigor index etc. was found to be higher at lower dose of radiation treatment as with increase in dose proline content also increased. The chlorophyll content in control was $8.44 \mathrm{mg} / \mathrm{g} \mathrm{FW}$ whereas, at $100 \mathrm{~Gy}$ it was increased to 12.2 $\mathrm{mg} / \mathrm{g}$. Bhumibhamon (1973), reported that with use of X-rays, gamma rays, light rays, high frequency sound waves etc. Improvement has been reported in Tectona to overcome dormancy and stimulate germination, but it also results in damage of chromosomes and other malformations.

In conclusion the mechanical scarification and conc. $\mathrm{H}_{2} \mathrm{SO}_{4}$ have been widely used to improve germination of several hard seed coat species. It disrupts the barrier for the uptake of water by the seed and permits radicle emergence by weakening coat structure. Acid treatment shows best results in leguminous tree species by breaking hard seed coat that permit unrestricted inflow of water in the seed and expands embryonic parts. Quick and early emergence of seeds by acid treatment is due to softening of the seed coat that induces absorption of water and gaseous exchange. Levels of thickness in seed coat among various species are the reason of different degree of response to different pre sowing treatment. Most of the Conifers generally have physiological dormancy, so stratification for $0-5{ }^{\circ} \mathrm{C}$ for $60-70$ days is better to overcame morphological and physiological dormancy. Low temperature and stratification period results in biochemical changes in seeds by transforming complicate food substances into simpler forms that are useful at the time of germination. Several growth regulators and chemicals are linked with seed germination and seedling growth, but the most important being gibberellic acid, Indole-3-Acetic-Acid, Kinetin, Potassium nitrate, Thiourea etc. $\mathrm{GA}_{3}$ 100-200 ppm for 1-2 days is beneficial for most of the species studied and it overcome embryo dormancy. $\mathrm{KNO}_{3}$ is also important chemical for germination enhancement in many species by reducing the effect of growth retardant $(\mathrm{ABA})$ and enhanced imbibition of water into cotyledons that create hormonal balance in the seed. Several other chemicals like thiourea, hydrogen peroxide etc. and new generation plant hormones like jasmonic acid, barssiosteriod etc. are also found to be beneficial in some species. Biological method by feeding pods to animals/microorganisms also shows maximum germination in species like acacia, Gmelina arborea etc. Irradiation treatment is used in some species for the activation of biochemical and physiological processes but their negative effects were also reported in studies. Their lower dose up to 10 Gy can be useful to improve seed germination growth of seedling. Therefore, seed dormancy is an important factor while doing any research trail or for large scale production of seedling in nursery. Seed dormancy varies with species, while going for sowing it is must to consider dormancy type and appropriate treatment to obtain good results.

\section{Acknowledgement}

The authors are thankful to Department of SAF, College of Forestry, Dr. Yaswant Singh Parmar University of Horticulture and Forestry Solan, and Department of Science and Technology for supporting financially as INSPIRE fellow and for their kind cooperation.

\section{References}

Ahmed, A. 1986. Some aspects of dry land afforestation in the Sudan with special reference to Acacia tortilis (Forsk.) Hayne, A senegal Wild. and Prosopis 
chilensis (Molina) Stuntz. Forest Ecology and Management. 16: 209221.

Ajmal, K. M., Gul, B. and Weber, D. J. 2009. Effect of Germination Regulating Chemicals on Seed Germination of Halogeton glomeratus for Alleviation of Salinity Stress. Pakistan Journal of Botany. 41(3): 1205-1212.

Akshatha, C. K. and Jegadeesan, S. 2013. Effect of gamma irradiation on germination, growth, and biochemical parameters of Terminalia arjuna Roxb. Radiation Protection and Environment. 36 (1): 38-44. Doi: 10.4103/0972-0464.121826

Ali, T., Hossein, P., Asghar, F., Salman, Z. and Alizcm, 2010. The effect of different treatments on improving seed germination characteristics in medicinal species of Descurainia sophia and Plantago ovata. African Journal of Biotechnology. 9(39): 6588-6593.

Allen, 1962. Factors affecting the viability and germination behavior of coniferous seed. V. Seed moisture content during stratification and secondary storage, Pseudotsuga menziesii (Mirb.) Franco. Forestry Chronicle. 38: 303-312.

Azad, S., Musa, Z., Abdul, M. 2010 Effects of pre-sowing treatments on seed germination of Melia azedarach. Journal of Forestry Research. 21(2): 193-196.

Bahrani, A. and Pourreza, J. 2012. Gibberlic Acid and Salicylic Acid Effects on Seed Germination and Seedlings Growth of Wheat (Triticum aestivum L.) Under Salt Stress Condition. World Applied Science Journal. 18(5): 633-641.

Baskin, C. C. and Baskin, J. M. 2014. Seeds: ecology, biogeography, and evolution of dormancy and germination, 2nd edn. San Diego, CA, USA: Academic/Elsevier.

Baskin, J. M. and Baskin, C. C. 2004. A classification system for seed dormancy. Seed Science Research. 14: $1-16$.

Bewley, J. D. and Black, M. 1994. Seeds Physiology of Development and Germination. Second Edition. New York, Plenum Press pp. 445.

Bhumibhamon, S. 1973. Seed problems in Thailand. In "Seed Processing" Proc. Symposium IUFRO Working Group on Seed Problems, Bergen, Vol. II, Paper 2.

Bisht, N. S. and Ahlawat, S. P. 1999. SFRI, Information Bulletin No. 7 on Seed Technology. State Forest Research Institute. Department of Environment \& Forests Government of Arunachal Pradesh Itanagar - 791111 (India).

Black, M. 1992. Control processes in germination and dormancy. Oxford Biology Readers Services No. 20 (Head J J and O F Lowenstein, eds). Oxford University Press London pp. 1-16.

Bryndum, K. 1966. The germination of teak. Natural History Bull. Siam Society 21: 75-86.

Charles, T., Cushwa, Roberte, E., Martin, and Robert, L. M. 1967. The Effects of Fire on Seed Germination. International Journal of Forestry Research. 250-254.

Chien, and Lin, 1994. Mechanism of hydrogen peroxide in improving the germination of Cinnamomum camphora seed. Seed Science and Technology. 22: 231-236.

Das, N. 2014. The Effect of Seed Sources Variation and Pre-sowing Treatments on the Seed Germination of Acacia catechu and Elaeocarpus floribundus Species in Bangladesh. International Journal of Forestry Research. 1-8. 
http://dx.doi.org/10.1155/2014/98419 4

Donohue, K., Dorn, L., Griffith, C., Kim, E., Aguilera, A., Chandra, R., Schmitt, J. 2005. Niche construction through germination cueing: life- history responses to timing of germination in Arabidopsis thaliana. Evolution. 59: 771-785.

Duguma, B., Kang, B. T. and Okali, D. U. U. 1988. Factors affecting germination of Leucaena (Leucaena leucocephala (Lam.) de Wit.) seed. Seed Science \& Technology. 16: 489-500.

Faridi, I. O., Samani, E. R. T., Kadiri, M. and Agboola, D. A. 2000. Studies on growth inhibitors and promoters in dormant and germinability seeds of Parkia biglobosa. Nigerian Journal of Botany. 13: 89-95.

Finch- Savage, W. E., Leubner- Metzger, G. 2006. Seed dormancy and the control of germination. New Phytologist. 171: 501-523.

Footitt, S., Douterelo- Soler, I., Clay, H., Finch- Savage, W. E. 2011. Dormancy cycling in Arabidopsis seeds is controlled by seasonally distinct hormone- signaling pathways. Proceedings of the National Academy of Sciences, USA. 108: 20236-20241.

Francoise, C., Qiong, X., Christophe, B., and Hayat, 2014. Ethylene, a key factor in the regulation of seed dormancy. Frontiers in Plant Science. 5: 539-541.

Gehlot, A. K. and Sen, N. 1998. Effect of acid scarification on per cent germination, vigour index and germination rate in Cressa cretica (Linn.). Journal of Eco physiology. 1: 79-82.

Goor, A. Y. and Barney, C. W. (1976). Forest tree planting in arid zones (2nd Ed.). Ronald Press, New York.

Gosling, 2015. Raising trees and shrubs from seed, practice guide, Forestry research Commission Edinburgh.
Groome, J. S., Lees, H. M. N. and Wigg, L. T. 1957. A summary of information on Pterocarpus angolensis. Common Forestry Bureau Oxford.18 (3-8): 153-162.

Jull, L. G. and Blazich, F. A. 2000. Seed germination of selected provenances of Atlantic white cedar as influenced by stratification temperature and light. Scientia Horticulturae. 35:132-135.

Kemp, R. H. 1975. Seed pretreatment and principles of nursery handling. In Report on FAO/DANIDA Training Course on Forest Seed Collection and Handling, Vol. II. FAO Rome.

Khullar, P., Thapliya, R. C., Beniwal, B. S., Vakshasya, R. K. and Sharma, A. 1991. Forest Seed publishing by the editor, directorial Board FRI Dehradun pp 450.

Leubner-Metzger, G. 2001. Brassinosteroids and gibberellins promote tobacco seed germination by distinct pathways. Planta. 213: 758-763.

Liu, J., Xue, T., and Shen, Y. 2019. Effect of Nitric Oxide on Seed Germination and Dormancy in Empress Trees. Horticulture Technology. 29(3): 271275. Doi: 04250:18.

Lynn, M. 1967. Ionizing radiations in forests and forestry (excluding the use of radio-active tracers). Forestry Abstracts 28 (1), Comm. For. Bureau Oxford.

Malik, A. R. and Shamet, G. S. 2009. Storage of Pinus gerardiana Seeds: Biochemical Changes and its Applicability as Vigour Test Research. Journal of Seed Science. 2(3): 48-55.

Malik, A. R., Shamet, G. S. and Ali, M. 2008. Seed stratification of Pinus geradiana Wall. Effected of stratification duration and temperature. Indian Forestry. 134(8): 1072-1078. 
Matilla A J (2000). Ethylene in seed formation and germination. Seed Science Research 10: 111-126.

Mir, N. A., Masoodi, T. H., Geelani, S. M., Wani, A. A. and Sofi, P. A. 2017. Regeneration status of Betula utilis D. Don (Bhojpatra) forest in north western Himalayas of Kashmir valley, India. Indian Journal of Agriculture Science. 87(7): 658-664.

Mir, N. A., Masoodi, T. H., Sofi, P. A., Mir, S. A., Malik, A. R. 2018. Determination of effect of stratification duration and $\mathrm{GA}_{3}$ on germination and growth of Betula utilis D. Don under temperate conditions of Kashmir Himalayas. Indian Journal Plant Physiol. 23: 536542.

Mir, N. A., Masoodi,T. H., Mali, A., Bhat, H. A., Aijaz-un-Nabi, Gatoo, A. A. 2014. Seed technology in high altitude conifers with special reference to temperate conifers of Kashmir valley. Environment ecology and conservation. 20(3): 1089-1099.

Mirzavandiani, S., Payam, V. 2016. Improved characterization of seed storage Pinus radiata with gibberellic acid $\left(\mathrm{GA}_{3}\right)$ and potassium nitrate $\left(\mathrm{KNO}_{3}\right)$. International Journal Forest Soil and Erosion. 6 (1): 13-18.

Missanjo, E. 2014. Effects of Different Pretreatments to the Seed on Seedling Emergence and Growth of Acacia polyacantha. International Journal of Forest Research. 2014: 1-6.

Miyosh, K. and Tadash, S. 1997. The Effects of Ethanol on the Germination of Seeds of Japonica and Indica Rice (Oryza sativa L.) under Anaerobic and Aerobic Conditions. Annals of Botany. 79: 391-395.

Mugloo, J. A. 2013. Standardization of Nursery technology for high level conifer spruce. Ph.D. Thesis Sher-e-
Kashmir University.

Mukaila, M., Muktar, K. and Agboola, D. A. 1997. Response of some Nigerian vegetables to plant growth regulator treatments. Revista Biologia Tropical. 44(1): 23-28.

Murthy, B. N. S. and Reddy, Y. N. 1989. Temperature dependence of seed germination and seedling growth in ber (Ziziphus mauritiana Lam.) and their modification by pre-sowing treatments. Seed Science and Technology. 18: 621-627.

Palani, M., Dasrhagir, M. G. and Kumaran, K. 1995. Effect of pre-sowing chemical treatment on germination and seedling growth in Acacia nilotica. International Tree Crops Journal. 8: $189-192$.

Pandiya, S. 1989. Improving Forest production through quality seeds. Journal of Tropical Fort. 5(11): 251255.

Paul, G. B., Patel, C. S. and Biswas, P. K. 1973. Changes in endogenous growth regulator in loblolly pine seeds during the process of stratification and germination. Physiology Plant. 28: 530-534.

Poisot, T., Bever, J. D., Nemri, A., Thrall, P. H., Hochberg, M. E. 2011. A conceptual framework for the evolution of ecological specialisation. Ecology Letters. 14: 841-851.

Prochazka, P., Stranc, P., Kupka, I., Stranc, J., Pazderu, K. 2015. Forest seed treatment with brassinosteroids to increase their germination under stress conditions. Journal of Forest Science. 61(7): 291-296.

Rawat, B. S., Sharma, C. M. and Ghildiyal, S. K. 2006. Improvement of seed germination in three important conifer species by Gibberellic acid $\left(\mathrm{GA}_{3}\right)$. Lyonia. 11: 23-30.

Schmidt, L. 2000. Dormancy and 
pretreatment. Extract from 'Guide to Handling of Tropical and Subtropical Forest Seed' Forest Seed Centre.

Sofi, P. and Bhardwaj, S. D. 2008. Effect of seed weight and presowing treatments for germination and seedling growth of Cedrus deodara. Skuast Journal of Research. 10: 156-160.

Sompherm, K. 1975. Planning and organization of seed collection. In Report on FAO/DANIDA Training Course on Forest Seed Collection and Handling Vol. 2, FAO Rome.

Sujatha, V. N. and Manjappa, K. 2007. Effect of pre-sowing treatments on seed germination of Melia azedarach. Karnataka Journal Agriculture Science. 28(2): 269-270.

Tanaka, Y. P. J., Brotherton, A. and Comfrom, P. C. 1991. Germination of stratified and non-stratified seeds of red alder at two germination temperatures. New Forestry. 5: 67-75.

Troup, R. S. 1921. The Silviculture of Indian Trees. 3 volumes. Clarendon Press, Oxford.
Venable, D. L. 2007. Bet hedging in a guild of desert annuals. Ecology. 88: 10861090

Wunder, W. G .1966. The handling of seed in Sudan forestry. Pamphlet No. 19, Sudan Forests Dept. and UNDP Forestry Research and Education Project. Forest Research Institute, Soba, Khartoum.

Yildiz, K., Yazici, C., Muradoglu, F. 2007. Effect of jasmonic acid on germination dormant and non dormant apple seeds. Asian Journal of Chemistry. 19(2): 1098-1102.

Zhang, Y., ShunBao, L. U. and HanDong, G. A. O. 2013. Effect of Gibberellic acid (GA) and stratification treatment on embryo ultrastructure of Taxus chinensis var. mairei seed. African Journal of Agriculture Research. 8(18):1962-1967.

Zhao, G. and Jiang,. X. 2014. Role of Gibberllin and Auxin in promoting seed germination and seedling vigour in Pinus massoniana. Forest Science. 60(2): 367-373.

\section{How to cite this article:}

Amanpreet Kaur, Avtar Singh and Rajesh Monga. 2020. Seed Germination Enhancement through Breaking Seed Dormancy: A Review in Tropical and Temperate Tree Species. Int.J.Curr.Microbiol.App.Sci. 9(09): 1673-1688. doi: https://doi.org/10.20546/ijcmas.2020.909.208 